\title{
The Role of Accounting Conservatism in Moderating the Determinants of Earning Quality
}

\author{
Elisabeth Putri Adilya Cahyani ${ }^{1}$ and Muhammad Khafid ${ }^{\bowtie 2}$ \\ Accounting Department, Economics Faculty, Universitas Negeri Semarang \\ $2^{\text {nd }}$ Floor L2 Building UNNES, Gunungpati, Semarang, 50229, Indonesia \\ DOI: http://dx.doi.org/10.15294/jda.v12i1.24482
}

Submitted: May $5^{\text {th }}, 2019$ Revised: September 15 ${ }^{\text {th }}, 2019$ Accepted: January 20 ${ }^{\text {th }}, 2020$ Published: March $31^{\text {th }}, 2020$

\begin{abstract}
The purpose of this research is to examine the effect of liquidity, profit growth, firm size, and board of commissioners on the quality of earnings with conservatism as a moderating variable. The population of this study was the manufacturing companies listed on the Indonesia Stock Exchange in 20152018. Sampling of the research used purposive sampling method has obtained 59 sample companies with 4 years of observation so that 239 units of analysis were obtained. The total unit of analysis was reduced by 103 outlier data, so that the data used became 133 data. The analysis techniques used in the research were descriptive statistical analysis technique and inferential regression analysis with moderating variable. The results show that liquidity, profit growth, and the board of commissioners have no effect on the quality of earnings. Meanwhile, accounting conservatism does not moderate the effect of liquidity and firm size on earnings quality. The failure of accounting conservatism as the moderating variable in this research model is interesting to be carried out by the further research by developing the appropriate conservatism measurement according to the characteristics of manufacturing companies.
\end{abstract}

Keywords: liquidity; profit growth; firm size; board of commissioners; earnings quality; accounting conservatism

How to cite (APA 6th Style)

Cahyani, E., \& Khafid, M. (2020). The Role of Accounting Conservatism in Moderating the Determinants of Earning Quality. Jurnal Dinamika Akuntansi, 12(1), 46-54. doi:https://doi. org/10.15294/jda.v12i1.24482

\section{INTRODUCTION}

Financial statements are basically the results (output) of the process of financial accounting activities after companies carry out its activities for a certain period to find out the latest financial condition. The financial statements that have been prepared by corporate management contain various financial informations which are important points for the company to assess the performance of the company's management in managing the company for a certain period. Aside from being a material for assessing the performance of company management, financial information is also used as one of the company's guidelines for decision making.

Profit is an important indicator and is often used (Soly \& Wijaya, 2017) as a benchmark in assessing the company's prospects in the future. In addition, profit is also one of the indicators to find out how companies manage company resources effectively and efficiently while still getting an increase in each period. The existence of an encouragement for company management to increase

author $(\bowtie)$

E-mail:muh_khafid@mail.unnes.ac.id 
company profits, not a few company managements to do things deviate from the profits presented. With this deviant practice, it gives an impact for the users of financial statements in making decisions that are not qualified because there is a difference between the information obtained and the actual condition of the company.

Qualified earnings is profit that is able to show the actual performance of the company (Kurniawan \& Khafid, 2016). Bellovary et al. (2005) stated that quality of earnings is the ability to determine the truth of a company's earnings and predict future earnings by considering earnings persistence. However, there are still some companies that deviate on the financial statements, so that it also influences the quality of the company's earnings.

The rise of fraud scandals in the presentation of financial statements by PT Tiga Pilar Sejahtera Food Tbk in the financial statements 2017 which were proven to have recorded overstatement of accounts receivable, inventories, and fixed assets of the TPSF Group which reached Rp 4 trillion, amounted to Rp 662 billion in sales accounts, and Rp 329 billion in EBITDA of Food Entity. A misstatement by AISA has been proven by the results of Ernest \& Young's Public Accounting Firm audit dated March 12, 2019 (Investasi.Kontan, 2019).

Based on the previous research, there are still differences in research results and research limitations. Some of these differences are research by (Zulman \& Naelufar, 2020), (Ardianti, 2018), which state that there is an effect of liquidity on earnings quality. Meanwhile, there are research by (Ginting, 2017), (Sadiah \& Priyadi, 2015) which give the result that there is no effect of liquidity on earnings quality. The next difference in the results of studies is the profit growth variable conducted by Czajor et. al. (2014) shows that profit growth affects on earnings quality. However, there are studies that contradict the previous research conducted by (Czajor et. al., 2014) which show that there is no effect of profit growth variable on earnings quality.

Furthermore, research of firm size on earnings quality has different research results Ananda \& Ningsih (2016), Tambun et al. (2017) that show the effect of firm size on earnings quality. This condition indicates that the higher the size of the company owned by the company, the higher the quality of the corporate earnings reported. There is also research by Aryengki et.al.(2016), Zulman \& Naelufar (2020), and Wati \& Putra (2017) which give result there is no effect of firm size on earnings quality. Meanwhile, the variable of the board of commissioners in the study Hashim \& Devi (2009) also gives result where there is an effect between the board of commissioners on earnings quality, meanwhile Khafid \& Arief (2017) gives the result that the board of commissioners has no effect on earnings quality. The variable of accounting conservatism is chosen as a moderating variable to moderate the effect of liquidity and firm size on earnings quality.

Agency theory explains that agency relationship arises when there is a principal that gives responsibility to agent to provide the best policy for the business being managed and providing a service (Jensen \& Meckling, 1976). The presence of parties who are trying to achieve their respective goals and targets, making this is vulnerable to conflict. Therefore, agency theory tries to provide an offer to minimize conflicts that occur as a result of differences in achievements of each party. To support the realization of good earnings quality, it is necessary to carry out supervision by the board of commissioners as a party that can balance the interests of the two parties, namely agent and principal. In addition, the presence of profit growth, firm size, and the presence of accounting conservatism can minimize agency conflicts.

Signal theory was developed by Ross (1977) revealed that the internal party of the company has better information about the condition of the company it manages and will be encouraged to publish this information to attract potential investors to invest so that it will affect the increase in the company's share price. The signal given to shareholders can be in the form of information about the company's performance for efforts to improve the quality and value of the company Hashim \& Devi (2009). Submission transparently and giving signals will improve the quality of earnings information. With the support of signal theory, it is expected that the company will be able to give signals of its financial performance accordingly.

Liquidity is the ratio used to measure the ability of a company to meet its short-term liabilities 
by taking into account the company's current assets to its current debt (Zulman \& Naelufar, 2020). Liquidity is also one of the important factors for cash flow to determine whether cash flow is in a good position or there is a problem. Thus, the company will strive for a high level of liquidity so that the resulted cash flow also shows maximum results. The presence of liquidity is expected to create signal theory to give an overview to the investors about the company's financial performance in the current period and in the future. Companies with high performance are expected to increase the quality of earnings. This is supported by research conducted by Setianingsih (2016), and Zulman \& Naelufar (2020) which state that liquidity has a positive effect on earnings quality. Thus, the research hypothesis is formulated as follows:

\section{H1: Liquidity has a positive effect on earnings quality.}

Low and high level of liquidity is able to affect the quality of earnings obtained by the company. In order to maintaining the stability of the company's earnings quality, it is needed the effort of company management in applying the accounting method. Conservative accounting method is a good enough indicator to reflect the quality of earnings. The presence of accounting conservatism is reinforced by the existence of agency theory. Aryengki et. al.(2016); Zulman \& Naelufar (2020) state that liquisdity has a positive effect on earnings quality, while research conducted by Ginting (2017), Putra \& Subowo 92016), state that there is no effect of liquidity on earnings quality. The presence of accounting conservatism is expected to be able to strengthen or weaken the liquidity effect on the earnings quality.

\section{H2: Accounting conservatism moderates the effect of liquidity on earnings quality.}

Profit growth is an indicator to assess the movement of increase or decrease on the profit generated by the company in each period. Companies with good profitability performance tend to trust themselves in reporting their earnings. This condition can be said that companies in their operational activities are able to increase their profits so that these profits continue to experience growth, reflecting that the companies have generated qualified profits and can provide an overview to the users of financial statements. The results of research conducted by Czajor et. al. (2014) which state that profit growth, which is one of the indicators of company performance, has an effect on earnings quality. A company that is able to maximize its profit every period will have a good performance.

\section{H3: Profit growth has a positive effect on earnings quality.}

Large-scale companies have a great opportunity to raise funds from investors so that they are able to use these funds to generate greater profits and in the end the corporate managements no longer manipulate profits due to the realization of these achievements. The proxy used for this variable is the natural logarithm of total assets. Thus, the higher the asset value, the higher the quality of the company's earnings. The firm size variable reflects how agency theory attempts to mediate between company management and investors. Research conducted by Sadiah \& Priyadi (2015), Fitriana \& Islami (2018), which give the result that firm size has a positive effect on earnings quality. This illustrates that the higher the size of the company, the higher the quality of the company's earnings. Large companies will maintain their reputation thus avoiding deviant action on their profits.

\section{H4: Firm size has a positive effect on earnings quality.}

The higher the size of the company, the more it is expected to be able to produce high-quality earnings. The presence of conservatism is expected to be able to help company management to obtain high-quality earnings. So that accounting conservatism can be one of the measurements that can be used to avoid agency conflicts that are aligned with the goals of agency theory. The results of the previous studies by Putra \& Subowo (2016), Fitriana \& Islami (2018), state that firm size has a positive effect on earnings quality, but there is also research by Aryengki et. al. (2016), Wati \& Putra (2017) state that there is no effect between firm size on the quality of earnings generated 
by the company. The number of inconsistencies of the results of the previous studies becomes the background of the firm size variable is chosen to be moderated by accounting conservatism. However, firm size does not seem to be able to affect the quality of earnings. The presence of accounting conservatism moderates the effect of firm size on earnings quality.

\section{H5: Accounting conservatism moderates the effect of firm size on earnings quality.}

The board of commissioners has an important role for the company in terms of monitoring the activities carried out by the company. Through an internal meeting of the board of commissioners, it is expected to be one of the encouragements for company management to report qualified earnings. When the quality of earnings presented in the financial statements has a good value, it can reduce agency conflict. Therefore, agency theory is able to explain the variable of the board of commissioners in the study. Research conducted by Hashim \& Devi (2009) and Nariman \& Ekadjaja (2018) show that the board of commissioners has a positive effect on earnings quality. The existence of the board of commissioners is expected to be one of the encouragements for company management to display quality profits to the interests of the company.

\section{H6: The board of commissioners has a positive effect on earnings quality.}

\section{RESEARCH METHODS}

This research was a research with quantitative approach and uses hypothesis testing study design to examine the effect on the variables that have been hypothesized in the study. The research data was secondary data taken from the annual report of the manufacturing companies that have been listed on the Indonesia Stock Exchange (IDX) for the period 2015 to 2018 through the Indonesia Stock Exchange website by downloading directly. In addition, there are a number of references to articles and books became literature studies in this research to compile the research framework and enrich the understanding of the researchers. The sampling technique in this study used purposive sampling technique resulted in 59 sample companies with 4 years of observation so that it obtained 236 units of analysis, minus 103 outlier data, then the data used became 133 data. The research data used a ratio scale that was processed using the IBM SPSS Statistics 21 application. The sample selection criteria table is as follows:

Table 1. Sample Selection Criteria

\begin{tabular}{lrr}
\hline \multicolumn{1}{c}{ Sample Criteria } & $\begin{array}{r}\text { Beyond } \\
\text { Criteria }\end{array}$ & $\begin{array}{r}\text { Included } \\
\text { Criteria }\end{array}$ \\
\hline $\begin{array}{l}\text { Manufacturing companies listed on the IDX in the 2016-2018 period } \\
\text { Companies do not use the rupiah currency in its financial statements 2016-2018 }\end{array}$ & $(26)$ \\
Companies do not provide information regarding the research variables, & $(3)$ \\
especially the board of commissioner variable & & \\
The companies suffered losses in the 2016-2018 period & $(26)$ \\
The number of samples selected in the study 2015-2018 & \\
Total observation periods & & 59 \\
Total analysis units & & 236 \\
Outlier data during the observation period & 103 \\
Total research data for the 2016-2018 period & & 133 \\
\hline Source: Secondary data processed, 2020. &
\end{tabular}


The table of variable operational definition is as follows:

Table 2. Operational Definition of Variable

\begin{tabular}{|c|c|c|c|}
\hline No & Variables & Definition & Indicators \\
\hline 1 & $\begin{array}{l}\text { Earnings } \\
\text { Quality }\end{array}$ & $\begin{array}{l}\text { Profit that is able to reflect the continu- } \\
\text { ation of profit in the future. (Khafid \& } \\
\text { Arief, 2017) }\end{array}$ & $\begin{array}{l}\mathrm{QE}=\text { Operating Activity Cash } \\
\text { Flow / Net profit } \\
\text { (Oktaviani } \text { et al., 2015) }\end{array}$ \\
\hline 2 & Liquidity & $\begin{array}{l}\text { The ability of company to meet its short- } \\
\text { term obligations by utilizing available as- } \\
\text { sets. (Nurhanifah \& Jaya, 2014) }\end{array}$ & $\begin{array}{l}\text { CR=Current Asset/Current Li- } \\
\text { abilities } \\
\text { (Khafid \& Arief, 2017) }\end{array}$ \\
\hline 3 & Profit Growth & $\begin{array}{l}\text { Comparison of current profits with pre- } \\
\text { vious period profits. } \\
\text { (Sadiah \& Priyadi, 2015). }\end{array}$ & $\begin{array}{l}\text { Profit Growth = Net Profit Year t - } \\
\text { Net Profit t-1 / Net Profit Year t-1 } \\
\text { x 100\%. (Sadiah \& Priyadi, 2015) }\end{array}$ \\
\hline 4 & Firm Size & $\begin{array}{l}\text { Company scale or category, large, me- } \\
\text { dium, small.(Arif, 2016) }\end{array}$ & LnTotal Assets. (Arif, 2016) \\
\hline 5 & $\begin{array}{l}\text { Board of } \\
\text { Commission- } \\
\text { ers }\end{array}$ & $\begin{array}{l}\text { The highest internal control mechanism } \\
\text { as a supervisor and controller of compa- } \\
\text { ny management. (Khafid \& Arief, 2017) }\end{array}$ & $\begin{array}{l}\text { Board of Commissioners Meet- } \\
\text { ing Frequency. } \\
\text { (Khafid \& Arief, 2017) }\end{array}$ \\
\hline 6 & $\begin{array}{l}\text { Accounting } \\
\text { conservatism }\end{array}$ & $\begin{array}{l}\text { A prudent attitude to financial reports } \\
\text { due to uncertain economic conditions } \\
\text { and protects investors. (Sugiarto \& } \\
\text { Fachrurrozie, 2018) }\end{array}$ & $\begin{array}{l}\text { Market to book ratio = Closing } \\
\text { Price/Book Value } \\
\text { (Sugiarto \& Fachrurrozie, 2016) }\end{array}$ \\
\hline
\end{tabular}

\section{RESULTS AND DISCUSSIONS}

The dependent variable in this study is quality of earnings (QE). Meanwhile, the independent variables in this study are liquidity (CR), profit growth (PG), firm size (LNTA), and board of commissioners (FRI). The moderating variable in this study is accounting conservatism (MTBR).

Table 3. Results of Descriptive Statistics Analysis

\begin{tabular}{lcrrrr}
\hline & \multicolumn{5}{c}{ Descriptive Statistics } \\
\hline EQ & $\mathrm{N}$ & Minimum & Maximum & Mean & Std. Deviation \\
CR & 133 & -.721 & 2.768 & 1.07587 & .703371 \\
PROV & 133 & 1.020 & 5.290 & 2.49143 & 1.135115 \\
LnTA & 133 & -.781 & 1.189 & .06762 & .391845 \\
Frek & 133 & 11.934 & 18.385 & 14.91347 & 1.627514 \\
MTBR & 133 & 1.000 & 12.000 & 6.48120 & 2.948039 \\
Valid N (listwise) & 133 & .120 & 5.875 & 2.25514 & 1.543269 \\
\hline
\end{tabular}

Source: Secondary data processed, 2020

The result of descriptive statistics on the earnings quality variable (EQ) listed in table 3. shows the minimum and maximum value ranges from -0.721 to 2.768 . The value of the standard deviation of earnings quality is 0.70337 with an average of 1.07587 . The value of the standard deviation on the earnings quality variable is smaller than the mean value which indicates that the deviation of data on this variable is quite good. Liquidity has a minimum and maximum value range of 1.020 to 5.290 which is shown in the results of descriptive statistics in table 3 . The mean value of the liquidity variable is 2.49143 with a standard deviation of 1.13511 . The liquidity variable also shows a standard deviation value that is lower than the mean value, it can be said that liquidity has good data deviation and the data variations tend to be homogeneous.

The results of descriptive statistics in table 3 for the variable of profit growth show a value range of -0.781 to 1.189 . The standard deviation value of the profit growth variable is 0.39184 with 
a mean value of 0.06762 , so it can be said that the deviation of data on the profit growth variable is not good. Firm size, which is proxied by total assets, shows a value range of 11.934 to 18.385 . In addition, the results of descriptive statistics in table 3 also show the standard deviation value of the firm size variable, namely 1.62751 and the mean value of 14.91347 . The firm size variable shows that the standard deviation is smaller than the calculated mean value, so it can be said that the deviation of data on the variable is good.

The variable of the board of commissioners in table 3 shows the value range of 1.000 to 12.000. The results of the descriptive statistics in table 3 provide information about the standard deviation value of the board of commissioners of 2.94803 and the mean value of 6.48120 . This condition illustrates that the standard deviation in the variable of the board of commissioners is smaller than the mean value, indicating that the data deviation on the variable of the board of commissioners is quite good because the data deviation is relatively homogeneous. Accounting conservatism in the results of descriptive statistics shows a value range of 0.120 to 5.875 . The results of descriptive statistics show a standard deviation value of 1.54326 with a calculated mean of 2.25514, indicating the result that is smaller than the value of the calculated mean, so that under these conditions the deviation of data on the accounting conservatism variable shows fairly good data because the distribution of data on this variable is not much different.

The normality test used in the study uses the Kolmogorov-Smirnov one-sample test. The data can be said to be normal if the value at asymptonic significance is more than 0.05 (sig $>0.05$ ). Based on the normality test, the asymptonic significant value is 0.590 , indicating that all research variables are normally distributed. The result of multicollinearity test shows that the data in the study does not find any multicollinearity. This result is evidenced by the results at the tolerance value of the independent variable $>0.10$ and the value at $\operatorname{VIF}<10$.

The autocorrelation test in this study uses the Run-Test. The results of the run test autocorrelation test show the test value of -0.01865 with Asym. Sig (2-tailed) of 0.509 at a significance of $5 \%$. This condition gives meaning that the residual is random so that there is no autocorrelation between residuals. The heteroscedasticity test in this study uses White test. The White test is calculated via $c^{2}=\mathrm{nx} \mathrm{R}^{2}$, so that if $\mathrm{c}^{2}$ count $<\mathrm{c}^{2}$ table, then it can be concluded that heteroscedasticity does not occur. The result of heteroscedasticity test through white test is known that $\mathrm{c}^{2}=133 \times 0.276$ resulting in 36.708 , whereas in the chi-square table it is known that $\mathrm{n}-1=(133$ $-1=132$ ), $\mathrm{n}$ as many as 132 with a probability level of 0.05 producing a value of 159.814 . Based on the results, it is known that $\mathrm{c}^{2}$ count is $36.708<\mathrm{c}^{2}$ table 159.814 , then heteroscedasticity does not occur in the regression model.

The value of Adjusted $\mathrm{R}^{2}$ is 0.034 . In this condition, it can be concluded that $3.4 \%$ of the variability of earnings quality which can be explained by the variables of liquidity, profit growth, firm size, the board of commissioners, and the interaction of the liquidity variable and firm size with the accounting conservatism variable. Meanwhile, the remaining value of $96.6 \%$ is explained by other variables outside the regression model in the study.

Table 4. Hypothesis Test Results

\begin{tabular}{lcccc}
\hline \multicolumn{1}{c}{ Hypothesis } & $\begin{array}{c}\text { Unstandardized } \\
\text { Coefficients } \beta\end{array}$ & Sig. & $\alpha$ & Results \\
\hline Liquidity has a positive effect on earnings quality & -0.103 & 0.135 & 0.05 & Rejected \\
Accounting conservatism moderates the effect of li- & -0.017 & 0.832 & 0.05 & Rejected \\
quidity on earnings quality & & & & \\
Profit growth has a positive effect on earnings quality & -0.088 & 0.172 & 0.05 & Rejected \\
Firm size has a positive effect on earnings quality & 0.165 & 0.017 & 0.05 & Accepted \\
Accounting conservatism moderates the effect of & -0.122 & 0.237 & 0.05 & Rejected \\
firm size on earnings quality & & & & \\
The board of commissioners has a positive effect on & -0.063 & 0.355 & 0.05 & Rejected \\
earnings quality & & & & \\
\hline
\end{tabular}

Source: Secondary data processed, 2020.

The results of this study indicate that liquidity has no effect on earnings quality, not in line 
with the explanation of the signal theory. The results of this study indicate that high liquidity does not guarantee that the company has high earnings quality. This is assumed that high liquidity is not necessarily an indicator of good performance. Liquidity that is too high can also be an indicator of the inability of the management to manage their current assets. There is also an assumption that there is a possibility that the company's management motive for increasing the profit is due to another motivation. The increase in the company's financial performance does not guarantee that there is a desire to pay attention to earnings quality. Thus, it can be said that liquidity has no effect on earnings quality. The result of this study regarding the liquidity variable has no effect on earnings quality is in line with the research conducted by Soly \& Wijaya (2017).

The result of the study shown in Table 4 . show the effect of profit growth variable on earnings quality variable of $0.172(0.172>0.05)$ indicating profit growth has no effect on earnings quality. The researchers assume that profit growth indicates that the magnitude of the push to meet the interests of shareholders which happens in corporate management. So that corporate management tends to increase company profits which are not necessarily accompanied by good earnings quality. The existence of profit growth in the company but does not guarantee the quality of corporate profits, contrary to agency theory, the result of the study is not able to reduce conflicts between corporate management and shareholders. The result of the study is in line with research conducted by Czajor et. al. (2014) which states that earnings growth does not significantly influence earnings quality.

In accordance with Table 4. which shows that the significance value of firm size is 0.017 $<0.05$ with a regression coefficient of 0.165 . This indicates that if there is an increase in the value of total assets, it will affect the increase in value of the company's earnings quality. The research is in accordance with research conducted by Ananda \& Ningsih (2016), Tambun et al. (2017), and Fitriana \& Islami (2018) which state that firm size has a significant positive effect on earnings quality. Companies with large size category are relative to be trusted by investors and creditors to deposit a number of funds. Large companies will minimize the practice of profit manipulation. This is due to large companies will maintain their image from deviant activities so as to give trust to investors and creditors that the profits generated from their operations are qualified earnings. So the larger the size of the company, the more qualified profit it has. The result of the study is in line with the goals of agency theory, namely minimizing agency conflict.

Based on the results of the hypothesis test that have been shown in Table 4. show the significance value of the board of commissioner variable that is $0.355>0.05$, the board of commissioners which is proxied by the frequency of internal meetings of the board of commissioners has no significant effect on earnings quality. The research is in line with research conducted by Khafid \& Arief (2017) and not in line with agency theory. Based on the results of the study, the researchers assume that the frequency of meetings conducted by the board of commissioners does not determine the quality of a company's profit. That is because the meeting conducted by the board of commissioners does not only discuss the company's earnings quality, but is more likely to discuss company policies globally. In addition, it can be indicated that the high internal meetings of the board of commissioners do not always indicate that the profits generated by the company are qualified earnings, because the high frequency of internal meetings does not always run effectively Khafid \& Arief (2017) to achieve the company's targets while remaining dedicated to obtaining good quality earnings.

Based on the results of the research, conservatism does not moderate the relationship between liquidity and earnings quality. The researchers assume that the low liquidity in the company's annual report is not caused by the implementation of accounting conservatism, but the company is experiencing a decline in its financial performance. The results of the study also contradict agency theory, that the presence of accounting conservatism is unable to minimize agency conflict. Another cause of the inability of accounting conservatism variable to moderate the relationship between liquidity and earnings quality is because the current ratio cannot measure and predict future cash inflows and outflows and adequacy of cash inflows for future cash outflows 
Subramanyam (2014); which is accompanied by the implementation of the precautionary principle or accounting conservatism.

The result of this study states that accounting conservatism does not moderate the relationship between firm size and earnings quality. The researchers assume that high firm size does not guarantee that the company implements accounting conservatism to its full potential so that it does not pay attention to the quality of the profits obtained. Large companies tend to increase assets to control market share, so they can increase profits. However, this does not ensure that the profits obtained are able to present qualified earnings. The results of the study contradict agency theory which aims to avoid information asymmetries or agency conflicts. The results of this study indicate that company management is motivated to increase the value of assets, where the size of the company does not guarantee the company to apply accounting conservatism to realize qualified earnings according to shareholders' expectations.

\section{CONCLUSIONS AND SUGGESTIONS}

Based on the results of the study, it is concluded that liquidity has no effect on earnings quality in the company. Profit growth does not have effect on earnings quality in the manufacturing companies. Firm size has a positive effect on earnings quality in manufacturing companies listed on the Indonesia Stock Exchange in 2015-2018. The board of commissioners has no effect on the quality of earnings in the manufacturing companies listed on the Indonesia Stock Exchange in 2015-2018. Accounting conservatism is not able to moderate liquidity on earnings quality in the manufacturing companies listed on the Indonesia Stock Exchange in 2015-2018. Accounting conservatism is not able to moderate liquidity on earnings quality in the manufacturing companies listed on the Indonesia Stock Exchange in 2015-2018.

The failure of accounting conservatism as the moderating variable in the research model is due to the inaccuracy in measuring this variable. This study uses the Market to Book ratio to measure accounting conservatism. Further research can use other proxies to measure this variable. In addition, it is expected to add other independent variables because based on the results of the coefficient of determination shows a very low value of $3.4 \%$, while the remaining $96.6 \%$ is explained by other variables and add to the sample year used.

\section{REFERENCES}

Ananda, R., \& Ningsih, E. S. (2016). Pengaruh Likuiditas, Kepemilikan Institusional, dan Ukuran Perusahaan Terhadap Kualitas Laba. Jurnal Ilmiah Mahasiswa Ekonomi Akuntansi, 1(2), 277-294.

Ardianti, R. (2018). Pengaruh Alokasi Pajak Antar Periode, Persistensi Laba, Profitabilitas, Dan Likuiditas Terhadap Kualitas Laba. Jurnal Akuntansi, 6(1), 85-102.

Arif, R. (2016). Pengaruh Struktur Modal, Resiko Sistematis, Kesempatan Bertumbuh Dan Ukuran Perusahaan Terhadap Earnings Response Coefficient (ERC). Jurnal Akuntansi, 4 (2), 1-26.

Aryengki, R., Satriawan, R.A., dan Rofika (2016). Pengaruh Komite Audit, Kualitas Audit, Likuiditas, dan Ukuran Perusahaan Terhadap Kualitas Laba Pada Perusahaan Industry \& Chemical Yang Terdaftar di Bursa Efek Indonesia Tahun 2011-2014. Jurnal Online Mahasiswa. 3(1), 1-20.

Bellovary, J. L., Giacomino, D.E., and Akers, M.D. (2005). Earnings Quality: It's Time to Measure and Report. The CPA Journal.32-37.

Czajor, P., Michalak, J., \& Michalak, H. W. (2014). Influence of Economy Growth on Earnings Quality of Listed Companies in Poland. Social Sciences. 82(4), 48-58.

Fitriana, V. E., \& Islami, I. N. (2018). The Relationship Of Firm Size, CEO Ability, Tax Aggressiveness, To Earnings Quality. International Journal of Economics, Commerce and Management, United Kingdom, VI(2), 495-508.

Ginting, S. (2017). Pengaruh Profitabilitas, Likuiditas Dan Ukuran Perusahaan Terhadap Kualitas Laba Pada Perusahaan Manufaktur Yang Terdaftar Di Bursa Efek Indonesia. Jurnal Wira Ekonomi Mikroskil:JWEM. 7(02), 227-236.

Hashim, H.A. \& Dewi, S. S. (2009). Board Characteristics, Ownership Structure and Earnings Quality: Malaysian Evidence. Research in Accounting in Emerging Economics. 8(1). 97-123.

Jensen, M. C., \& Meckling, W. H. (1976). Theory of The Firm : Managerial Behavior, Agency Costs And 
Ownership Structure. Journal of Financial Economics, 3, 305-360.

Khafid, M. \& Arief, S. (2017). Managerial Ownership, Corporate Governance and Earnings Quality: The Role of Institutional Ownership as Moderating Variable. Pertanika Journal Social Sciences \& Humanities. 25(S), 241 - 254

Kurniawan, A. R., \& Khafid, M. (2016). Factors Affecting The Quality Of Profit In Indonesia Banking Companies. Jurnal Dinamika Akuntansi. 8(1), 30-38.

Nariman, A., \& Ekadjaja, M. (2018). Implikasi Corporate Governance, Investment Opportunity Set, Firm Size, Dan Leverage Terhadap Earnings Quality. Jurnal Ekonomi. 23(1), 33-47.

Nurhanifah, Y. A., \& Jaya, T. E. (2014). Pengaruh Alokasi Pajak Antar Periode, Investment Opportunity Set dan Likuiditas Terhadap Kualitas Laba. Jurnal Ilmiah Wahana Akuntansi. 9(2), 109-133.

Oktaviani, R. N., Nur, E., \& Ratnawati, V. (2015). Pengaruh Good Corporate Governance Terhadap Kualitas Laba Dengan Manajemen Laba Sebagai Variabel Intervening. Jurnal SOROT, 10(1), 36-53.

Putra, N. Y., \& Subowo. (2016). The Effect of Accounting Conservatism, Investment Opportunity Set , Leverage, and Company Size on Earnings Quality. Accounting Analysis Journal, 5(4), 299-306.

Ross, S. A. (1977). The determination of Financial Structure: The Incentive-Signalling Approach. The Bell Journal of Economics, 8(1), 23-40.

Sadiah, H., \& Priyadi, M. P. (2015). Pengaruh Leverage, Likuiditas, Size, Pertumbuhan Laba Dan Ios Terhadap Kualitas Laba. Jurnal Ilmu dan Riset Akuntansi. 4(5), 1-21.

Setianingsih, L. (2016). Pengaruh Investment Opportunity Set, Likuiditas dan Good Corporate Governance Terhadap Kualitas Laba Pada Perusahaan Manufaktur. Jurnal Universitas Pandanaran Semarang, 2(2), 1-17.

Soly, N., \& Wijaya, N. (2017). Faktor-Faktor Yang Mempengaruhi Kualitas Laba Pada Perusahaan Manufaktur. Jurnal Bisnis Dan Akuntansi, 19(1), 47-55.

Soyemi, K. A. \& Olawale, L. S. 2019. Firm Characteristics and Financial Reporting Quality: Evidence from Non Financial Firm in Nigeria. International Journal of Economics and Accounting. 27(2), 445-472.

Sugiarto, H.V.S \& Fachrurrozie. 2018. The Determinant of Accounting Conservatism on Manufacturing Companies in Indonesia. Accounting Analysis Journal. 7(1). 1-9.

Tambun, S., Sitorus, R. R., Panjaitan, I., \& Hardiah, A. Z. (2017). The Effect Of Good Corporate Governance and Audit Quality On The Earnings Quality Moderated By Firm Size. International Journal of Business, Economics and Law, 14(5), 48-56.

Wati, G. P., \& Putra, I. W. (2017). Pengaruh Ukuran Perusahaan, Leverage, Dan Good Corporate Governance Pada Kualitas Laba. Gahani. E-Jurnal Akuntansi. 19(1), 137-167.

Zulman, M., \& Naelufar, Y. (2020). Analysis of Profit Growth, Profitability, capital Structure, Liquidity and Copany Size of Profit Quality. Jurnal Akademi Akuntansi. 3(2), 12-35. 